\title{
The 100 most cited articles in metastatic spine disease
}

\author{
Jonathan Cohen, BA, Nima Alan, MD, James Zhou, BS, and D. Kojo Hamilton, MD \\ Department of Neurological Surgery, University of Pittsburgh School of Medicine, Pittsburgh, Pennsylvania
}

OBJECTIVE Despite the growing neurosurgical literature, a subset of pioneering studies have significantly impacted the field of metastatic spine disease. The purpose of this study was to identify and analyze the 100 most frequently cited articles in the field.

METHODS A keyword search using the Thomson Reuters Web of Science was conducted to identify articles relevant to the field of metastatic spine disease. The results were filtered based on title and abstract analysis to identify the 100 most cited articles. Statistical analysis was used to characterize journal frequency, past and current citations, citation distribution over time, and author frequency.

RESULTS The total number of citations for the final 100 articles ranged from 74 to 1169 . Articles selected for the final list were published between 1940 and 2009. The years in which the greatest numbers of top-100 studies were published were 1990 and 2005, and the greatest number of citations occurred in 2012. The majority of articles were published in the journals Spine (15), Cancer (11), and the Journal of Neurosurgery (9). Forty-four individuals were listed as authors on 2 articles, 9 were listed as authors on 3 articles, and 2 were listed as authors on 4 articles in the top 100 list. The most cited article was the work by Batson (1169 citations) that was published in 1940 and described the role of the vertebral veins in the spread of metastases. The second most cited article was Patchell's 2005 study (594 citations) discussing decompressive resection of spinal cord metastases. The third most cited article was the 1978 study by Gilbert that evaluated treatment of epidural spinal cord compression due to metastatic tumor (560 citations).

CONCLUSIONS The field of metastatic spine disease has witnessed numerous milestones and so it is increasingly important to recognize studies that have influenced the field. In this bibliographic study the authors identified and analyzed the most influential articles in the field of metastatic spine disease.

http://thejns.org/doi/abs/10.3171/2016.5.FOCUS16158

KEY WORDS metastatic spine disease; spine tumor; bibliographic; literature analysis

$\mathrm{T}$ HE clinical management of metastatic diseases of the spine is often debatable due to a lack of consensus regarding appropriate therapies. Throughout the growing body of neurosurgical literature addressing the subject, particular studies have significantly contributed to knowledge of the field. Due to the wealth of research articles relating to metastatic spine disease, critically important work often gets overlooked. Methods that help quantify the impact of scientific articles have been previously described ${ }^{30,80}$ One such tool, citation analysis, is based on the principle that the greater an article's influence, the more frequently it would be cited. In this report, we use citation analysis to identify the 100 most cited scientific articles that pertain to metastatic disease of the spine.

\section{Methods}

All databases and journals included in Thomson Reuters Web of Science were used to identify eligible studies.
The literature query was conducted using the following search command: (spine or spinal or vertebral or column or canal) and (primary or metastatic or metastasis or neoplas* or tumor*).

The search was performed using the "basic search" feature under the "title" category and included all articles published before 2016. The initial search yielded 19,831 results. The search results were then sorted on the basis of decreasing citation count.

Upon review of the title and abstract of the articles from the search output, and elimination of the impertinent articles, we identified the top 150 most cited articles on metastatic spine disease. We extended our search to beyond the top 100 articles in order to allow for replacing articles that might be excluded due to excessive self-citation. Only 2 papers ${ }^{66,75}$ were excluded on the basis of having a large percentage of self-citations ( $>40 \%$ of the total number of citations being in other works by authors of those papers). The remaining articles were ranked based on citation count, 


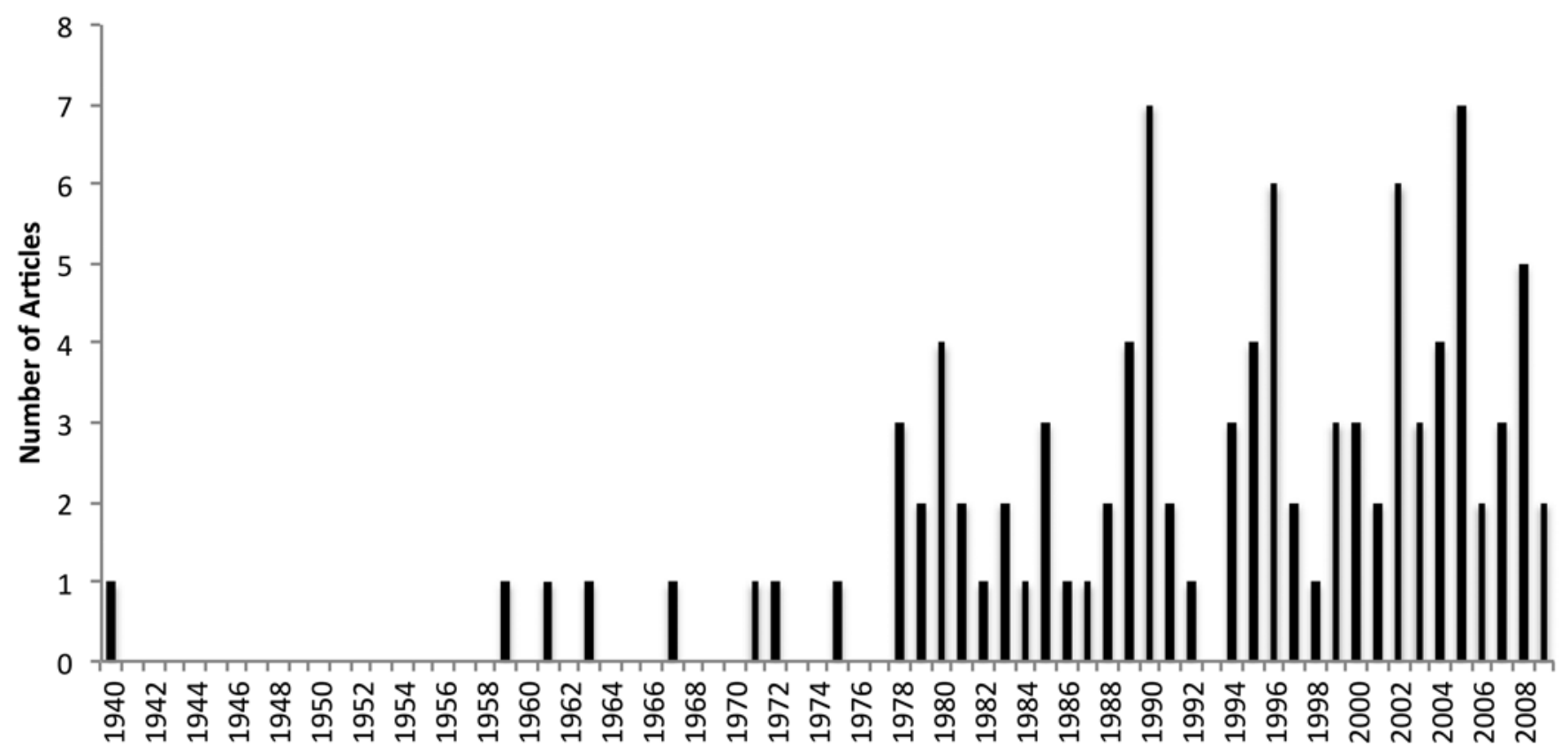

FIG. 1. Graph displaying the number of top 100 articles published each year from 1940 through 2015 .

and the top 100 most cited articles were included in the final list.

\section{Results}

A total of 19,831 articles matched our search criteria. Based on title and abstract review, the 100 most cited articles relevant to metastatic spine disease were selected. The top 100 articles, including their authors and year of publication, article topic, article summary, article type, level of evidence, number of citations, citations in the past year (2015), and citation rate (average citations per year) are shown in Table 1 . The total number of citations for the final 100 articles ranged from 74 to 1169 , with an average of 148.4 citations per article. The oldest article was published in 1940 by Batson ${ }^{9}$ and described the role of vertebral veins in metastatic spread to the spine. The most recent article was the 2009 study by Rose et al., ${ }^{71}$ evaluating the risk of fracture after image-guided intensity-modulated radiation therapy. The most productive publication years were 1990 and 2005, with 7 articles having been published in each year (Fig. 1). Articles were published in 40 different journals (Fig. 2). The most studies were published in the journal Spine (15), followed by Cancer (11), and the Journal of Neurosurgery (9). Eighty-three first authors contributed to articles on the final list. Eleven authors were credited with having multiple articles on the list. Two of these 11 individuals, Tomita ${ }^{90-93}$ and Harrington, ${ }^{41-44}$ were listed as authors in 4 articles on the final list.

The most frequently cited article was also the earliest publication in the list, the above-mentioned article by Batson, published in 1940 in the Annals of Surgery ${ }^{9}$ and describing the architecture of the vertebral veins and their role in the metastatic spread of tumors. This article has been consistently cited since its publication, receiving the most citations (27) in 1997 (Fig. 3). The second most cited article was the 2005 article by Patchell et al. ${ }^{65}$ which assessed the efficacy of decompressive surgery for spinal cord compression due to metastatic cancer. Citations of this article peaked in 2012, with 92 citations in that year alone (Fig. 4). The 1978 study by Gilbert et al., ${ }^{36}$ published in Annals of Neurology, is the third most cited article. This study discusses diagnostic criteria and treatment options for patients with epidural spinal cord compression due to metastatic tumor. This article was most cited in 1985, with 28 citations during that year (Fig. 5).

We defined citation rate as the number of citations per year. The ranking of citation rates for each article on the final list is shown in Table 2. The 2005 study by Patchell et al. had the highest overall citation rate, with an average of 54.0 citations per year. ${ }^{65}$ This was followed by the 2007 article by Gerszten et al. ${ }^{33}$ (28.6 citations per year) on radiosurgery for spinal metastases and the 2001 article by Tomita et al. ${ }^{91}$ (22.7 citations per year), which discussed a novel prognostic scoring system for surgical management of spinal metastases.

We also measured the number of citations an article received during the past year (2015). The article cited most frequently was written by Patchell et al. and published in 2005 and was cited 98 times during $2015 .{ }^{65}$ We also performed a linear regression to determine the relationship between an article's total number of citations and the number of times it was cited in the previous year. Our results determined that the total number of citations of an article correlates with the number of times it was cited in the preceding year (Fig. 6).

\section{Discussion}

Neurosurgical literature is replete with novel studies that, while helpful in advancing the field, pose burdens for physicians in their pursuit to identify studies that have sig- 


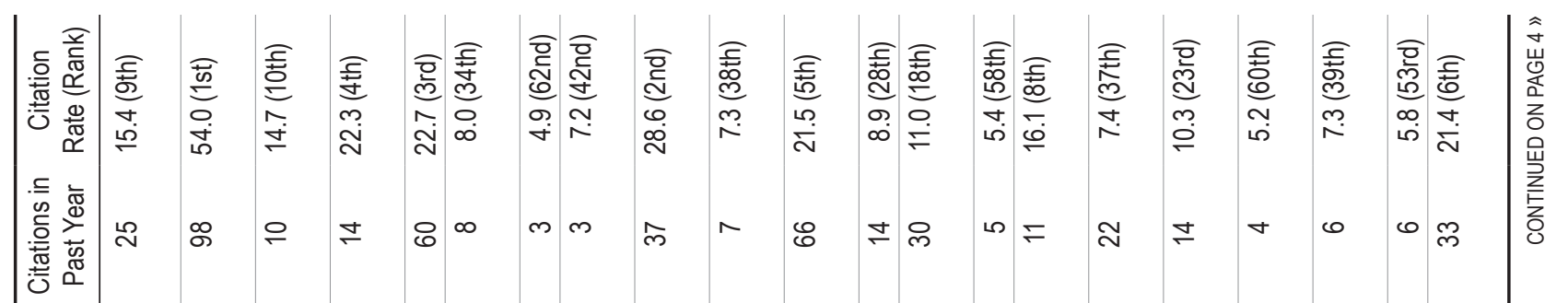

恶

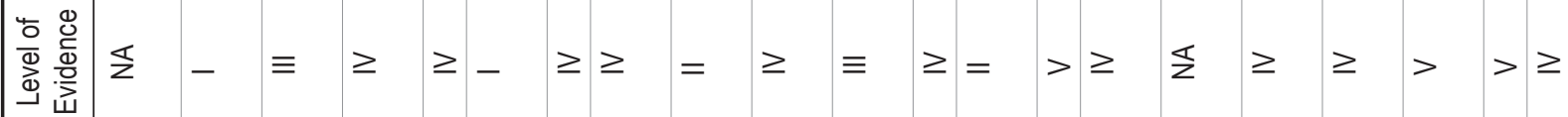

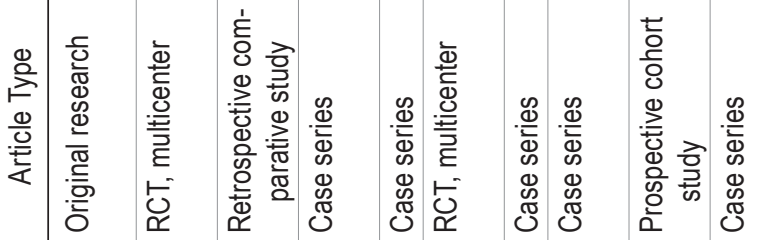

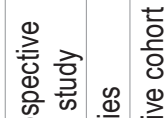

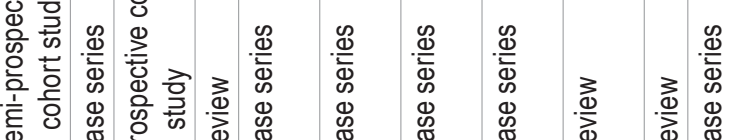

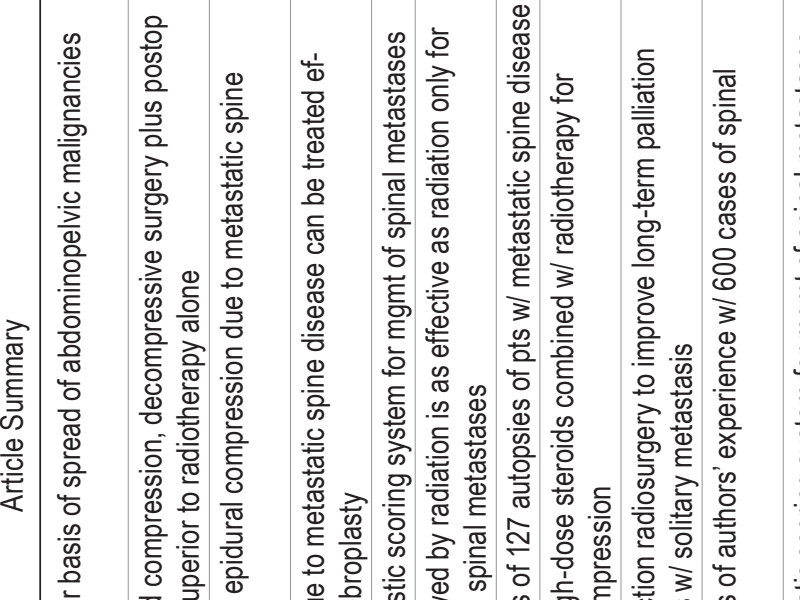
竞

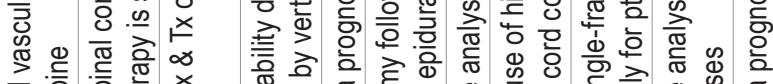
西

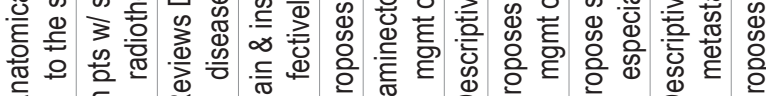
$\begin{array}{lllllllllll}0 & 0 & \simeq & 0 & 0 & 0 & 0 & \simeq & \propto & 0\end{array}$

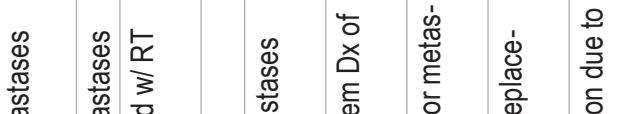
焉

离

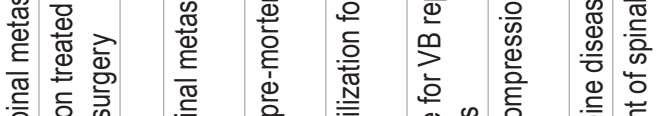

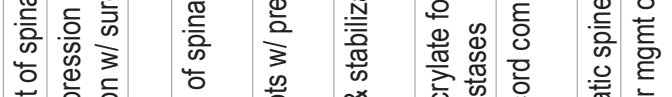

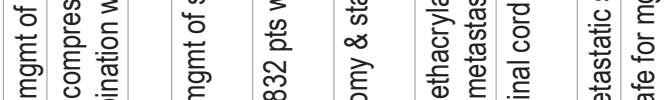

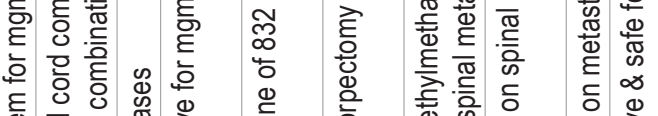

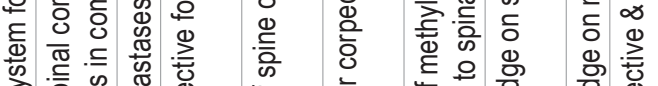

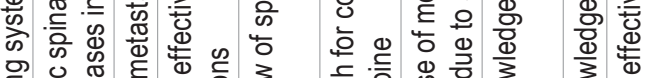

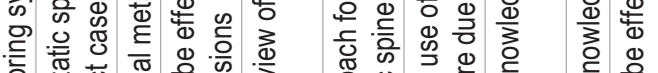

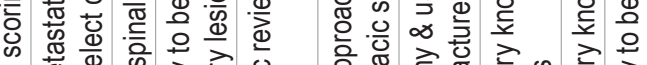

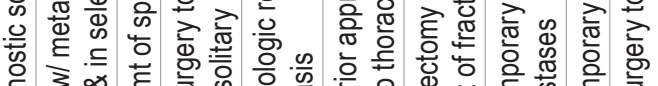

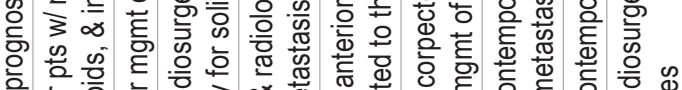
ब

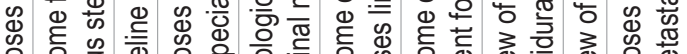

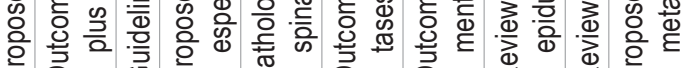

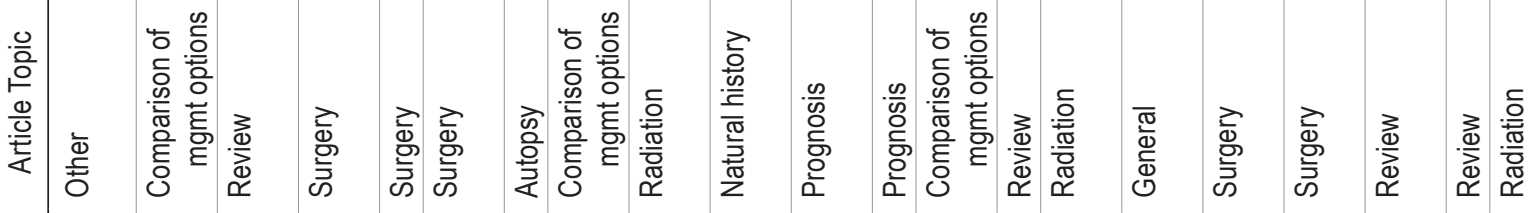

용

œ

䆣|

㟧

西

政

$\frac{\bar{\sigma}}{\overline{0}}$

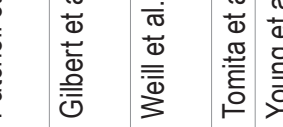

$\frac{\sqrt{\pi}}{\bar{\pi}}$

西

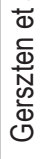

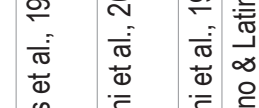

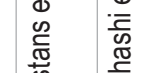

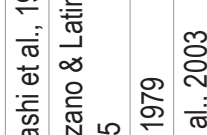

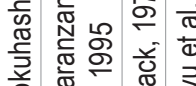

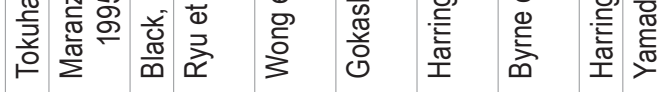

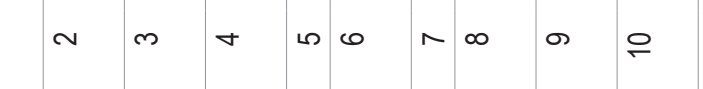

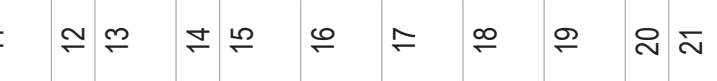




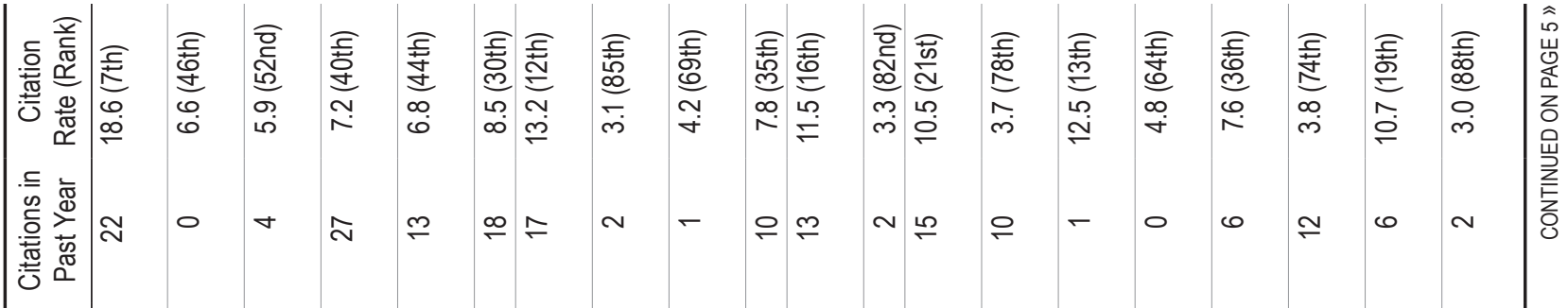

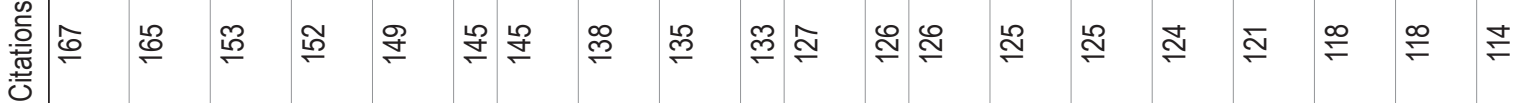

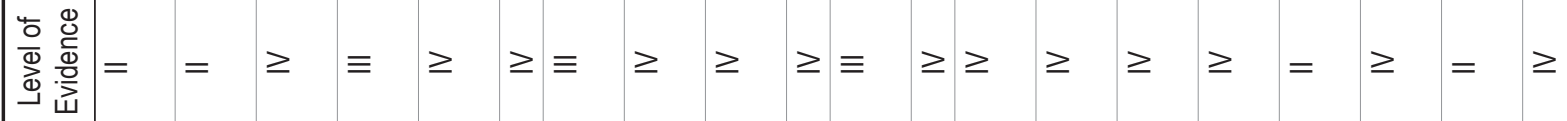

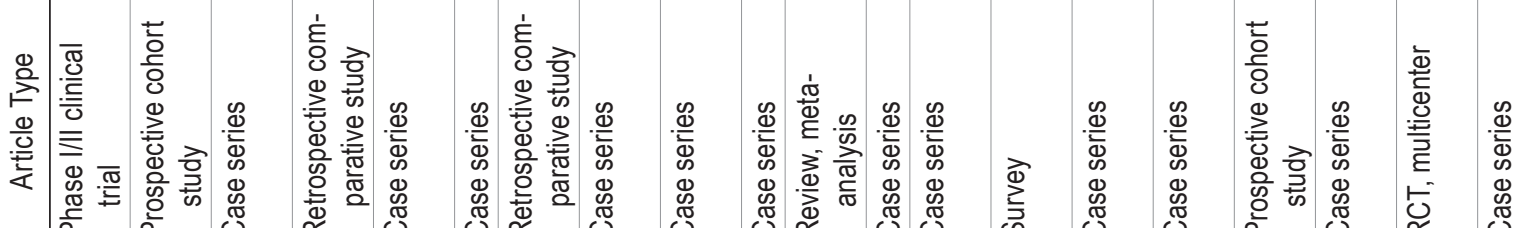

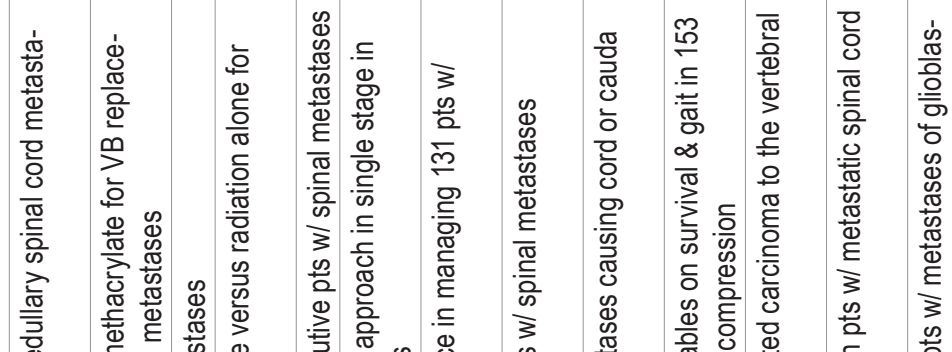

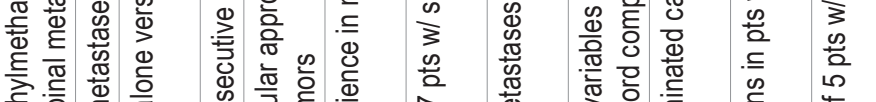

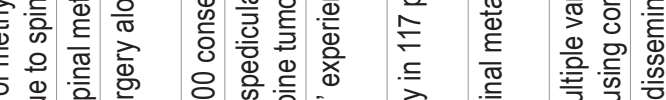

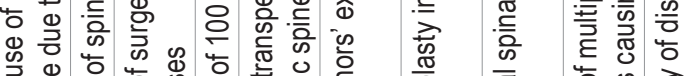
क 焉

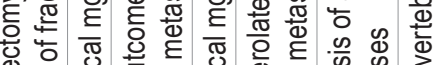

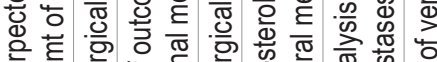

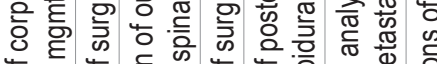

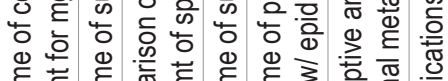
흥. 흘

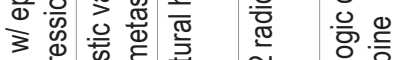

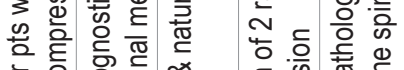

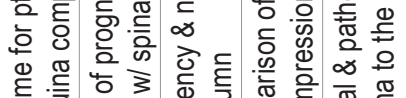

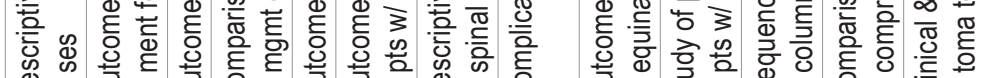

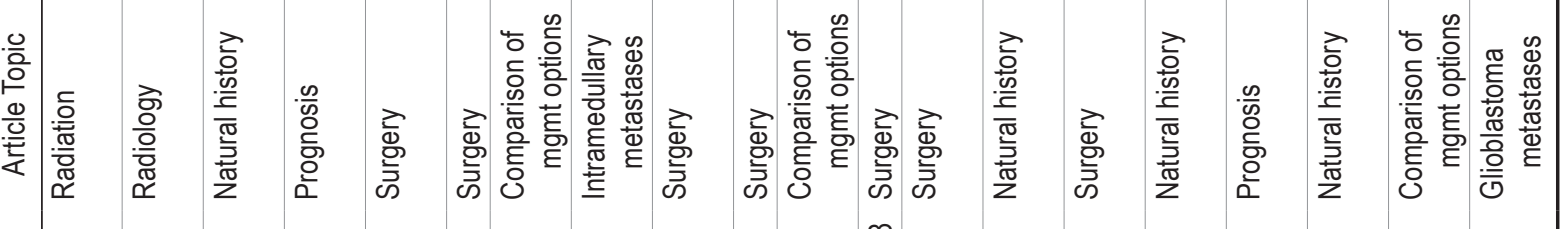

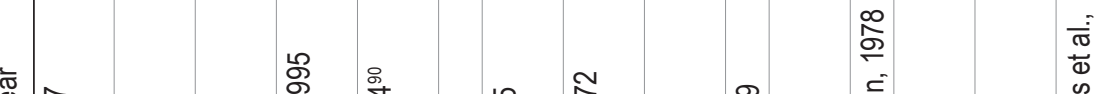
先

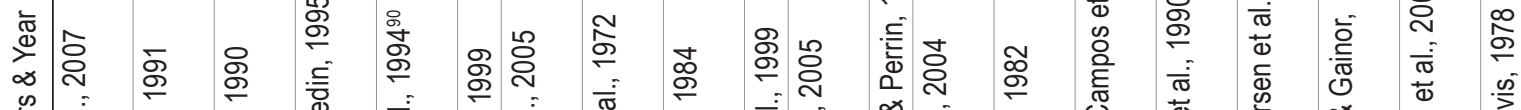

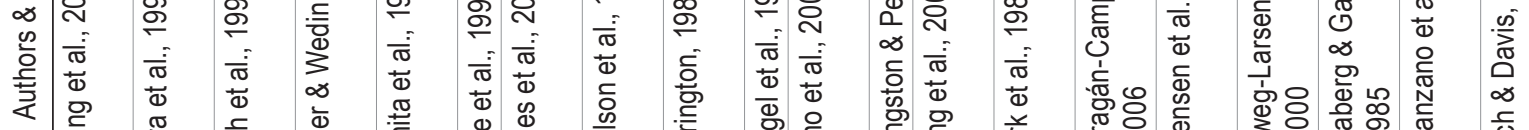

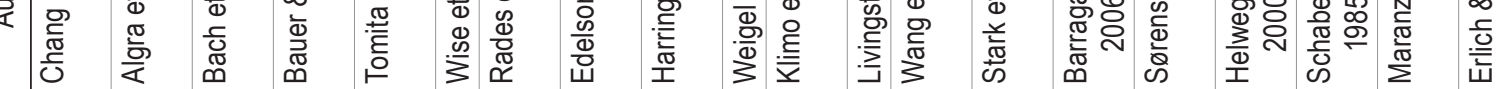
总 ఇ 趈

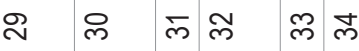




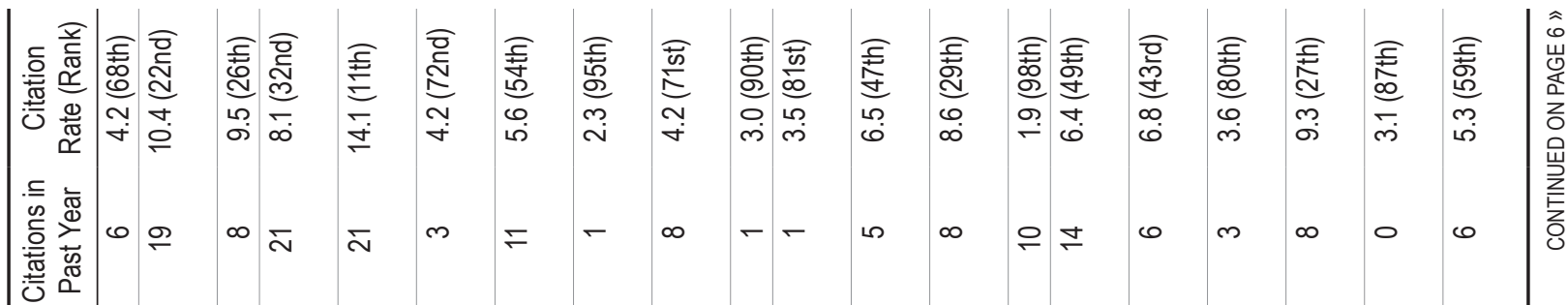

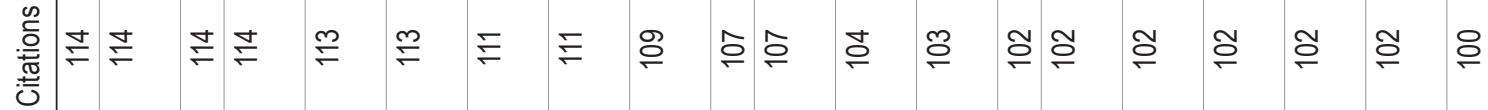

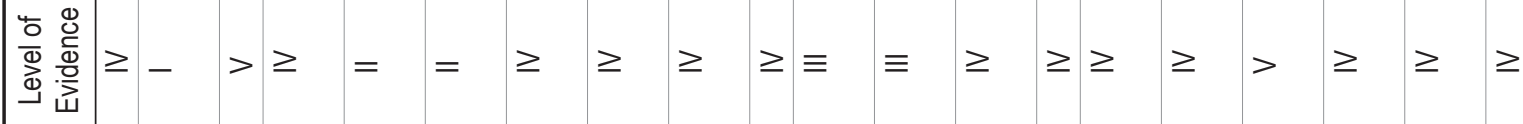

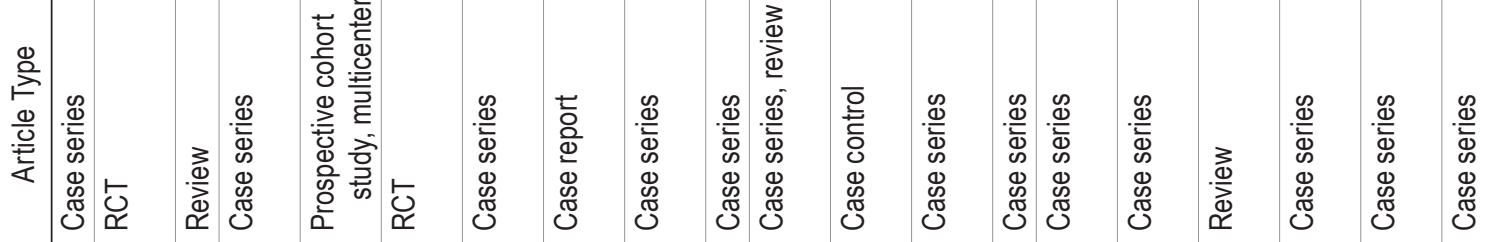

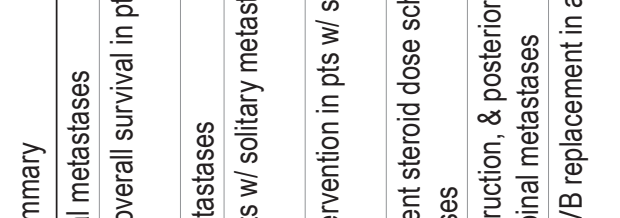

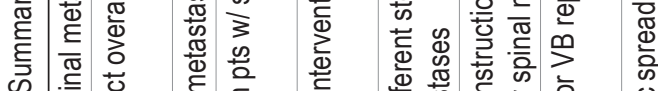

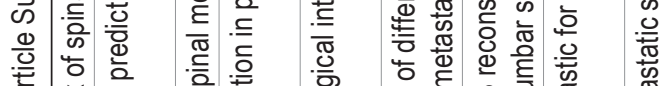

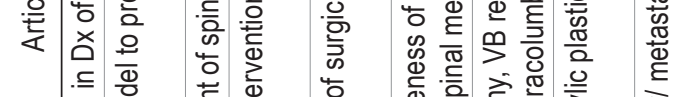

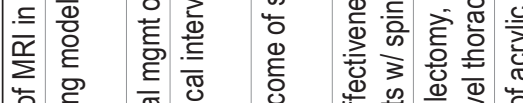
帝

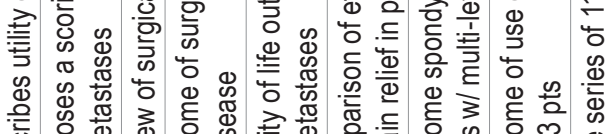

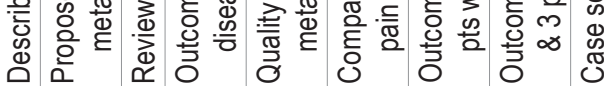

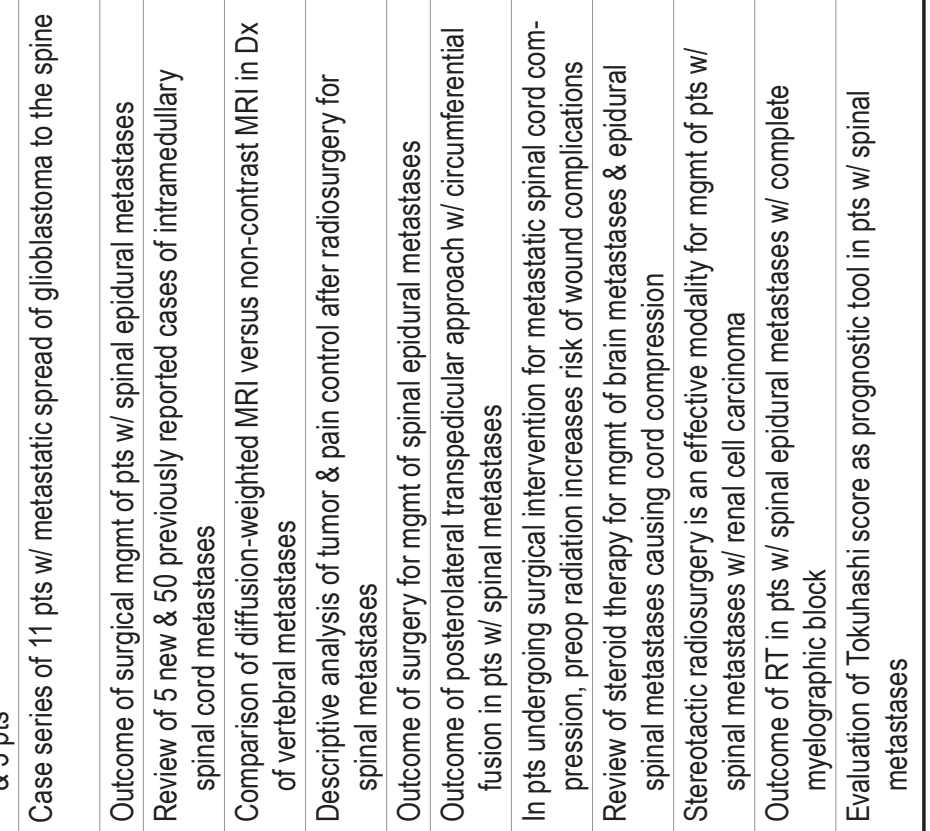

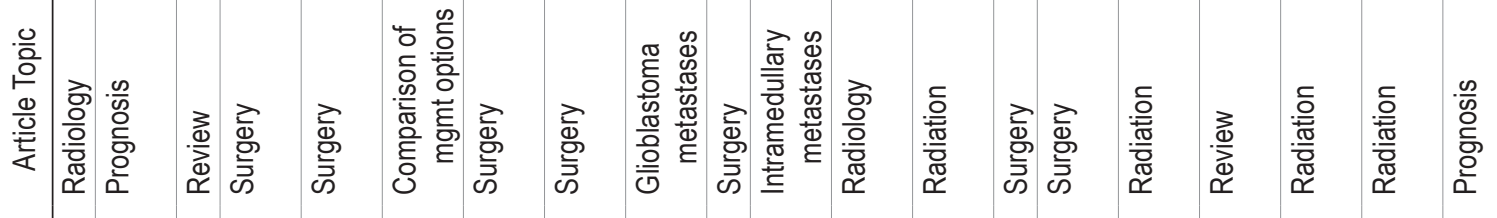

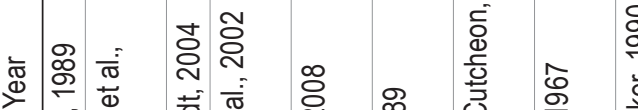

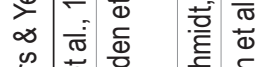

ํ. 躷

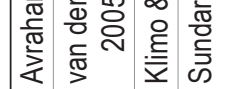
产

离

i $\sum_{\infty}^{\frac{\pi}{\pi}}$

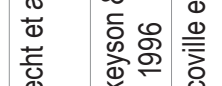

离

욤 


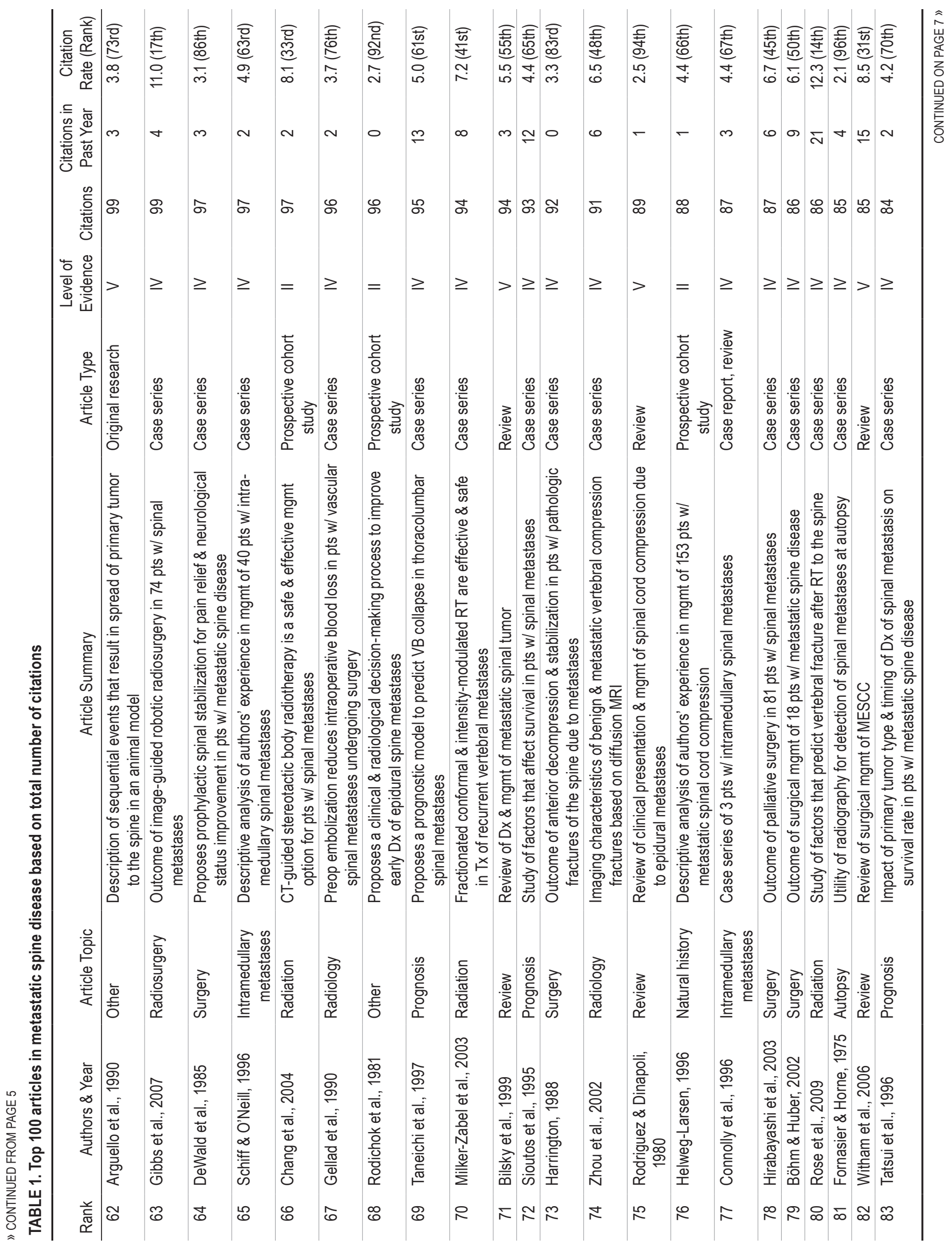




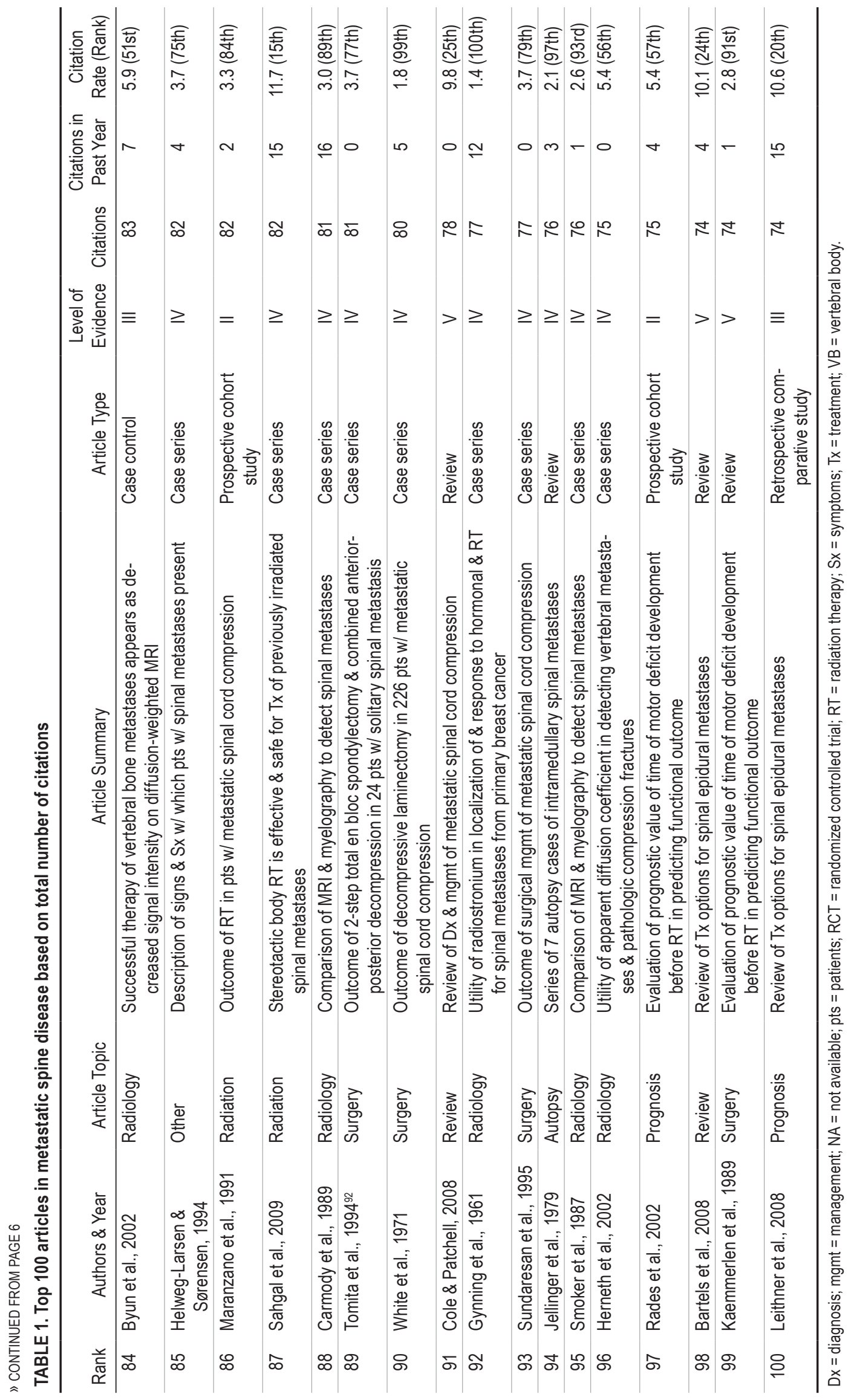




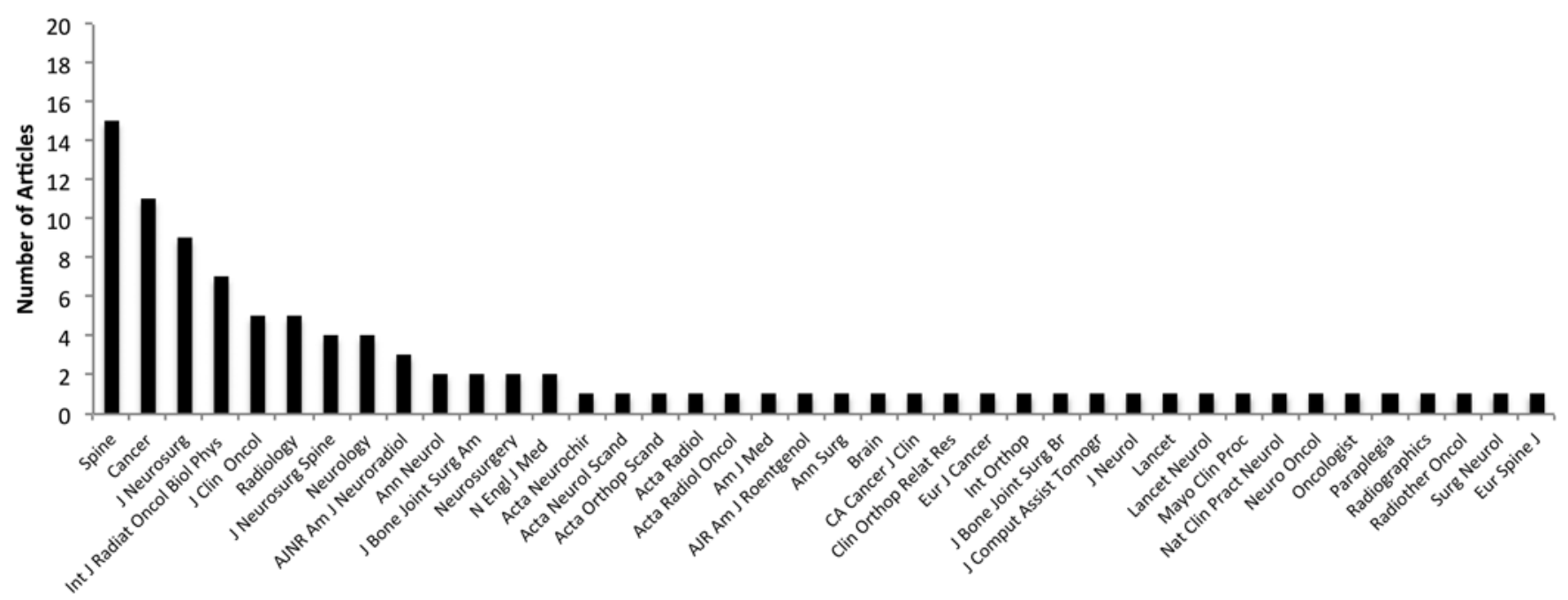

FIG. 2. Graph displaying the number of top 100 articles published by each journal.

nificantly impacted neurosurgical practice. Our aim was to identify the 100 most cited articles on metastatic spine disease. These frequently cited articles provide insight into the founding and development of the field, as well as current trends. In this study we performed citation analysis, wherein we measure the impact of articles, authors, and journals based on the number of times a work has been cited.

The most cited article in metastatic spine disease was Batson's 1940 article in the Annals of Surgery. ${ }^{9}$ In this landmark study, the author provides an anatomical explanation for the dissemination of spinal tumors from abdominopelvic primary tumors. In this paper, Batson described the anatomical distribution of the vertebral venous system in detail and, based on data from vessel injection experiments whereby dissemination was tracked, proposed an explanation for the metastatic spread of tumors from the abdomen or pelvis to the spine. This study has been consistently cited since publication in 1940, with a total of 1169 citations, and it received the greatest number of citations in 1998. Batson's work is considered a "classic," and some suggest that older papers are more likely to be cited. ${ }^{54}$

The second most cited article was the 2005 paper by Patchell et al., which sought to determine the role of surgery in the treatment of metastatic epidural spinal cord compression (MESCC). ${ }^{65}$ In their prospective randomized trial, the authors demonstrated that decompressive surgery followed by postoperative radiotherapy resulted in improved patient outcomes (i.e., retention of the ability to walk) compared with radiotherapy alone. The results indicate that surgery followed by radiotherapy may well be the

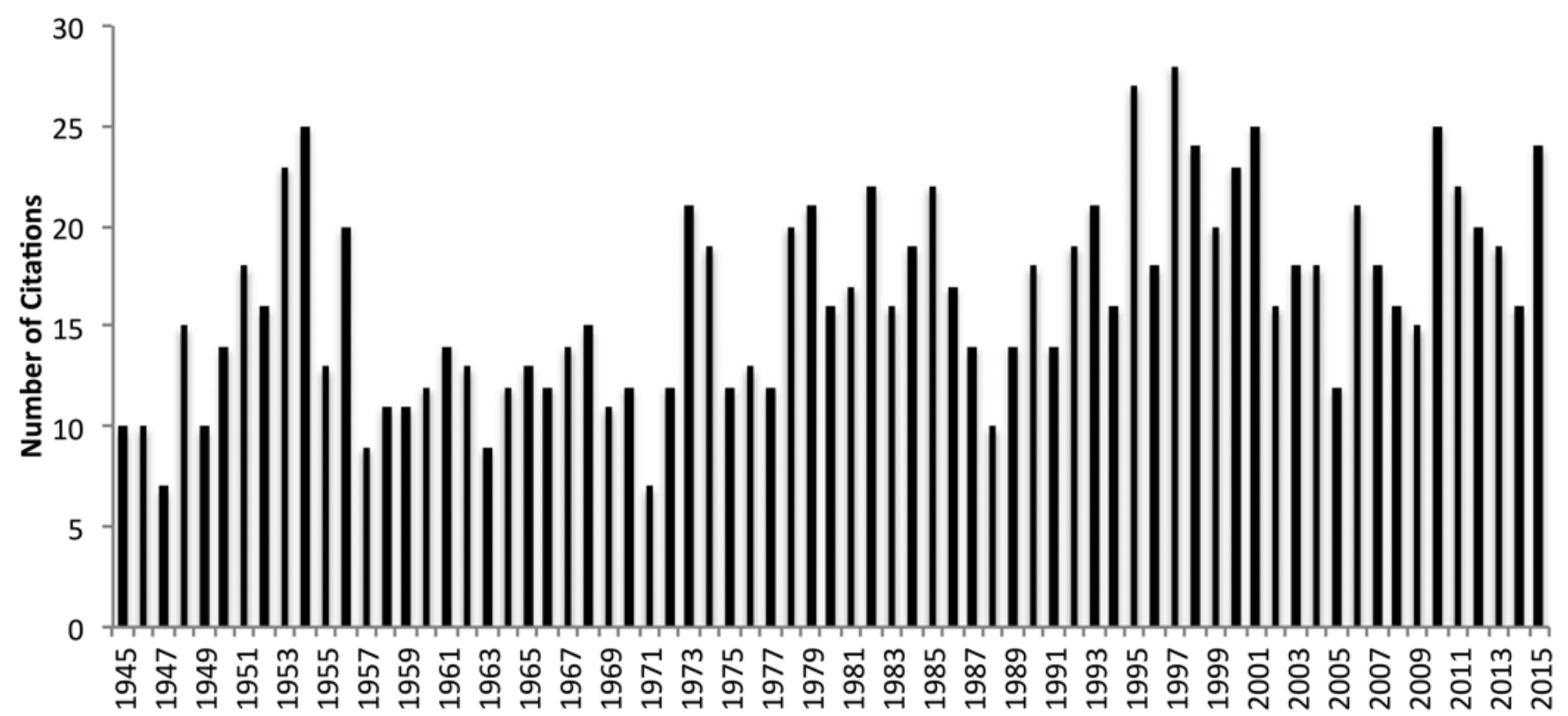

FIG. 3. Graph displaying citations per year of Batson's 1940 article titled "The function of the vertebral veins and their role in the spread of metastases."9 


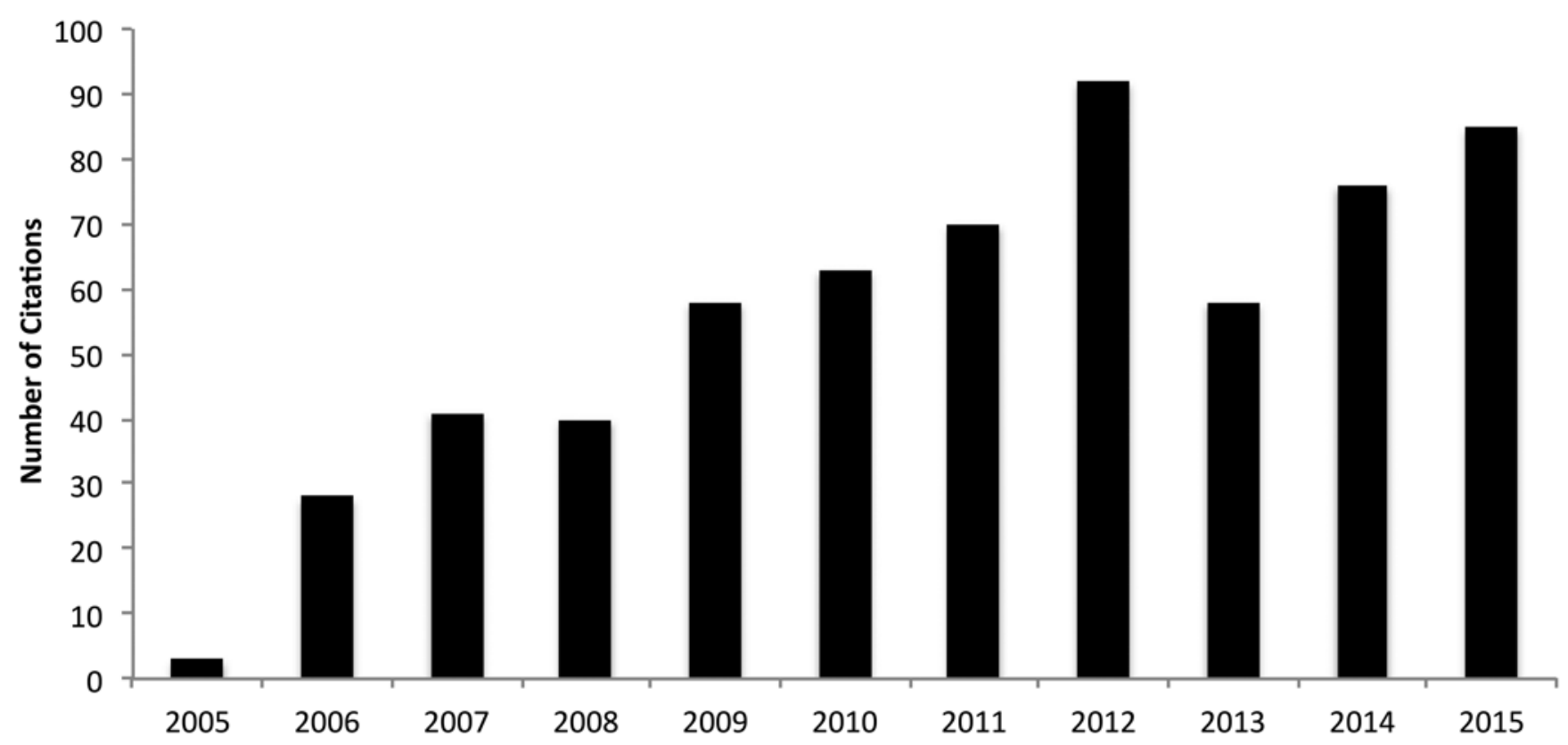

FIG. 4. Graph displaying citations per year for the 2005 article by Patchell et al. titled "Direct decompressive surgical resection in the treatment of spinal cord compression caused by metastatic cancer: a randomised trial." ${ }^{5}$

most effective treatment for MESCC. Despite not being the most cited article overall, the study is accumulating citations at a rapid pace. Since its publication in 2005, it has been cited 594 times, with an average of 54 citations per year. This is comparatively faster than the Batson study, which has received an average of 15.4 citations per year. Although recent, the influence of the Patchell et al. study is demonstrated by the rate with which this paper has been cited in the neurosurgical literature.
The third most cited article was written by Gilbert et al. and published in $1978 .{ }^{36}$ In this report, the authors compared the efficacy of radiotherapy alone versus laminectomy followed by radiotherapy for spinal cord compression due to extradural tumors. They concluded that radiotherapy alone was as effective as laminectomy plus radiotherapy in treating epidural spinal cord compression caused by metastatic cancer. Based on these results, surgical treatment (i.e., laminectomy) for MESCC was

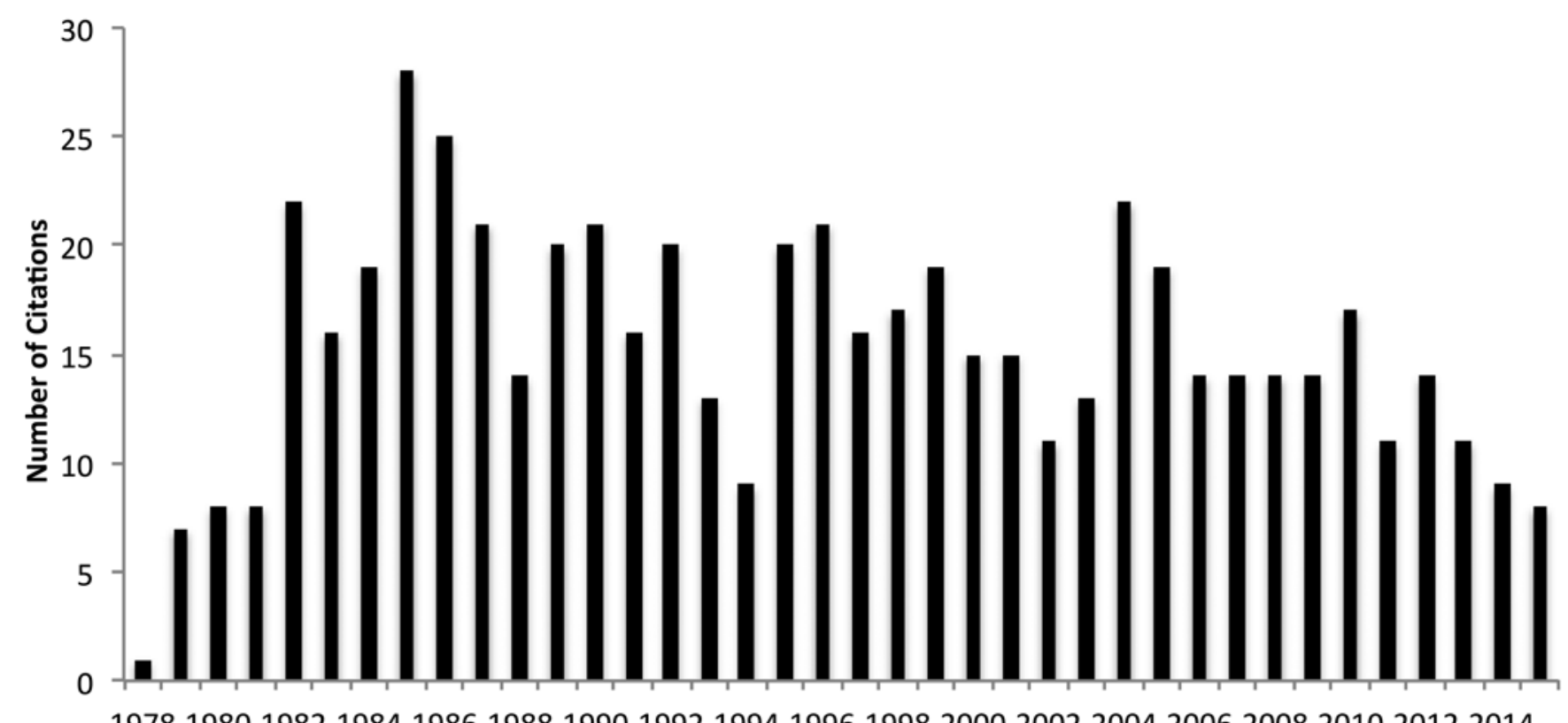

1978198019821984198619881990199219941996199820002002200420062008201020122014

FIG. 5. Graph displaying the citations per year for the 1978 article by Gilbert et al. titled "Epidural spinal cord compression from metastatic tumor: diagnosis and treatment." ${ }^{6}$ 
TABLE 2. Top 100 articles on metastatic spine disease ranked on the basis of citation rate (citations per year)

\begin{tabular}{|c|c|c|}
\hline Rank & Article & Citation Rate \\
\hline 1 & Patchell et al., 2005 & 54.0 \\
\hline 2 & Gerszten et al., 2005 & 28.6 \\
\hline 3 & Tomita et al., 2001 & 22.7 \\
\hline 4 & Weill et al., 1996 & 22.3 \\
\hline 5 & Tokuhashi et al., 2005 & 21.5 \\
\hline 6 & Yamada et al., 2008 & 21.4 \\
\hline 7 & Chang et al., 2007 & 18.6 \\
\hline 8 & Ryu et al., 2003 & 16.1 \\
\hline 9 & Batson, 1940 & 15.4 \\
\hline 10 & Gilbert et al., 1978 & 14.7 \\
\hline 11 & Ibrahim et al., 2008 & 14.1 \\
\hline 12 & Rades et al., 2005 & 13.2 \\
\hline 13 & Barragán-Campos et al., 2006 & 12.5 \\
\hline 14 & Rose et al., 2009 & 12.3 \\
\hline 15 & Sahgal et al., 2009 & 11.7 \\
\hline 16 & Klimo et al., 2005 & 11.5 \\
\hline 18 & Gibbs et al., 2007 & 11.0 \\
\hline 17 & Maranzano et al., 1991 & 11.0 \\
\hline 19 & Maranzano et al., 2005 & 10.7 \\
\hline 20 & Leithner et al., 2008 & 10.6 \\
\hline 21 & Wang et al., 2004 & 10.5 \\
\hline 22 & van der Linden et al., 2005 & 10.4 \\
\hline 23 & Gokaslan et al., 1998 & 10.3 \\
\hline 24 & Bartels et al., 2008 & 10.1 \\
\hline 25 & Cole \& Patchell, 2008 & 9.8 \\
\hline 26 & Klimo \& Schmidt, 2004 & 9.5 \\
\hline 27 & Gerszten et al., 2007 & 9.3 \\
\hline 28 & Tokuhashi et al., 1990 & 8.9 \\
\hline 29 & Ryu et al., 2004 & 8.6 \\
\hline 30 & Wise et al., 1999 & 8.5 \\
\hline 31 & Witham et al., 2006 & 8.5 \\
\hline 33 & Chang et al., 2004 & 8.1 \\
\hline 32 & Sundaresan et al., 1995 & 8.1 \\
\hline 34 & Young et al., 1980 & 8.0 \\
\hline 35 & Weigel et al., 1999 & 7.8 \\
\hline 36 & Helweg-Larsen, 1996 & 7.6 \\
\hline 37 & Wong et al., 1990 & 7.4 \\
\hline 39 & Byrne, 1992 & 7.3 \\
\hline 38 & Constans et al., 1983 & 7.3 \\
\hline 41 & Bauer \& Wedin, 1995 & 7.2 \\
\hline 40 & Greenberg et al., 1980 & 7.2 \\
\hline 42 & Milker-Zabel et al., 2003 & 7.2 \\
\hline 44 & Ghogawala et al., 2001 & 6.8 \\
\hline 43 & Tomita et al., $1994^{92}$ & 6.8 \\
\hline 45 & Hirabayashi et al., 2003 & 6.7 \\
\hline 46 & Algra et al., 1991 & 6.6 \\
\hline 47 & Castillo et al., 2000 & 6.5 \\
\hline 48 & Zhou et al., 2002 & 6.5 \\
\hline
\end{tabular}

CONTINUED IN NEXT COLUMN »
" CONTINUED FROM PREVIOUS COLUMN

TABLE 2. Top 100 articles on metastatic spine disease ranked on the basis of citation rate (citations per year)

\begin{tabular}{|c|c|c|}
\hline Rank & Article & Citation Rate \\
\hline 49 & Bilsky et al., 1999 & 6.4 \\
\hline 50 & Böhm \& Huber, 2002 & 6.1 \\
\hline 51 & Bach et al., 1990 & 5.9 \\
\hline 52 & Byun et al., 2002 & 5.9 \\
\hline 53 & Harrington, 1984 & 5.8 \\
\hline 54 & Akeyson \& McCutcheon, 1996 & 5.6 \\
\hline 55 & Bilsky et al., 2000 & 5.5 \\
\hline 56 & Black, 1979 & 5.4 \\
\hline 57 & Herneth et al., 2002 & 5.4 \\
\hline 58 & Rades et al., 2002 & 5.4 \\
\hline 59 & Enkaoua et al., 1997 & 5.3 \\
\hline 60 & Harrington, 1988 & 5.2 \\
\hline 61 & Taneichi et al., 1997 & 5.0 \\
\hline 62 & Barron et al., 1959 & 4.9 \\
\hline 63 & Schiff \& O'Neill, 1996 & 4.9 \\
\hline 64 & Sørensen et al., 1990 & 4.8 \\
\hline 67 & Connolly et al., 1996 & 4.4 \\
\hline 66 & Helweg-Larsen et al., 2000 & 4.4 \\
\hline 65 & Sioutos et al., 1995 & 4.4 \\
\hline 69 & Avrahami et al., 1989 & 4.2 \\
\hline 68 & Harrington, 1986 & 4.2 \\
\hline 72 & Tatsui et al., 1996 & 4.2 \\
\hline 70 & Vecht et al., 1989 & 4.2 \\
\hline 71 & Vertosick et al., 1990 & 4.2 \\
\hline 74 & Arguello et al., 1990 & 3.8 \\
\hline 73 & Schaberg \& Gainor, 1985 & 3.8 \\
\hline 76 & Gellad et al., 1990 & 3.7 \\
\hline 77 & Helweg-Larsen \& Sørensen, 1994 & 3.7 \\
\hline 75 & Stark et al., 1982 & 3.7 \\
\hline 79 & Sundaresan et al., 2002 & 3.7 \\
\hline 78 & Tomita et al., 1983 & 3.7 \\
\hline 80 & Weissman, 1988 & 3.6 \\
\hline 81 & Grem et al., 1985 & 3.5 \\
\hline 83 & Harrington, 1981 & 3.3 \\
\hline 82 & Livingston et al., 1978 & 3.3 \\
\hline 84 & Maranzano et al., 1995 & 3.3 \\
\hline 87 & DeWald et al., 1985 & 3.1 \\
\hline 85 & Edelson et al., 1972 & 3.1 \\
\hline 86 & Tomita et al., $1994^{90}$ & 3.1 \\
\hline 90 & Carmody et al., 1989 & 3.0 \\
\hline 89 & Dunn et al., 1980 & 3.0 \\
\hline 88 & Erlich \& Davis, 1978 & 3.0 \\
\hline 91 & Kaemmerlen et al., 1989 & 2.8 \\
\hline 92 & Rodichok et al., 1981 & 2.7 \\
\hline 93 & Smoker et al., 1987 & 2.6 \\
\hline 94 & Rodriguez \& Dinapoli, 1980 & 2.5 \\
\hline 95 & Scoville et al., 1967 & 2.3 \\
\hline
\end{tabular}

CONTINUED ON PAGE $11 »$ 
» CONTINUED FROM PAGE 10

TABLE 2. Top 100 articles on metastatic spine disease ranked on the basis of citation rate (citations per year)

\begin{tabular}{rlc}
\hline Rank & \multicolumn{1}{c}{ Article } & Citation Rate \\
\hline 96 & Fornasier \& Horne, 1975 & 2.1 \\
\hline 97 & Jellinger et al., 1979 & 2.1 \\
\hline 98 & Wright, 1963 & 1.9 \\
\hline 99 & White et al., 1971 & 1.8 \\
\hline 100 & Gynning et al., 1961 & 1.4 \\
\hline
\end{tabular}

deemed unnecessary. However, the work by Patchell and colleagues challenged this notion by demonstrating the efficacy of decompressive surgery for management of MESCC.

Among the most frequently cited articles, publication dates ranged from 1940 (for Batson's article) to as recent as 2009 (for the study by Rose et al., which evaluated the risk of fracture following single fraction image-guided intensity-modulated radiation therapy for spinal metastases $\left.^{71}\right)$. Articles relating to the topic of metastatic spine disease have become increasingly frequent, with most articles having been published in 1990 and 2005. The reason underlying these publication trends is not fully understood. An argument could be made that historical developments in the neurosurgical field, such as novel technologies or techniques, could be responsible for certain publication trends. For example, our data show a dramatic rise in the number of top 100 articles published during the 1980s. During this time, the first MRI of the spine was performed, and publication trends may reflect the emergence of this technology.

If an article were indeed influential, as measured by number of citations, we reasoned that it would continue to have an impact on current practice. One would expect that influential articles would continue to be cited as new articles in the field emerge. To address this we analyzed the relationship of the number of citations within the preceding year (2015) as a function of total number of citations of an article. As predicted, we found a positive correlation between these 2 factors, suggesting that impactful studies are more likely to be referenced by recently published articles and continue to influence current work.

The largest number of articles pertaining to metastatic spine disease were published in the journal Spine. It is important to note that a journal's contribution to a particular field may be the result of the number of years it has been in circulation and/or the frequency with which it is published. Spine is a biweekly peer-reviewed journal and thus its appearance on the top 100 list may reflect the frequency of publication. Furthermore, journals or articles that cover multiple disciplines, will at times attract a larger reader base, which can increase the exposure of an article. Other authors have studied the effect of degree of disciplinarity on citation impact and have found this relationship to be complex. ${ }^{107}$

Although citation analysis is a powerful tool for measuring an article's impact, citation count alone does not completely reveal an article's influence on the field. Selfcitation is arguably the most confounding factor influenc-

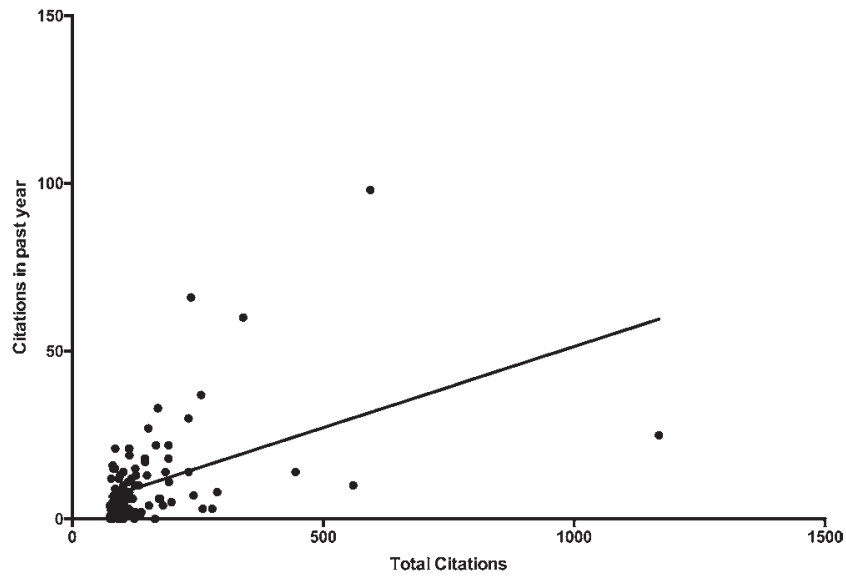

FIG. 6. Correlation between an article's total citations and number citations in the past year (2015).

ing citation analysis ${ }^{51,59}$ For different reasons, authors may cite their own papers, which increases citation numbers and the eventual impact of their article. This can skew citation analysis, as it becomes difficult to distinguish between articles that are frequently referenced due to their impact on the field and those that are frequently self-cited. Within our final list, nearly all articles were cited by 1 or more of their authors in subsequent publications at least once. For most articles, self-citations comprised a small fraction of the total citations. In some cases, a considerable percentage of the total citations were made by the articles' authors. More detailed analysis is warranted to determine the prevalence of self-citation and its influence on an article's impact. Another limitation of citation analysis is the concept of "obliteration by incorporation," which is based on the idea that information from "classic" papers is cited less frequently as it is absorbed into the body of existing knowledge..$^{63}$ Other limitations that have been described elsewhere include "incomplete citations," whereby certain citations are made as a means to persuade the reader rather than recognize work that has contributed to the field. ${ }^{54}$ It is important that future studies address how these factors influence citation trends and that a novel method-one that accounts for these factors-is developed to improve our system for classifying the impact of an article.

\section{Conclusions}

Although citation analysis does not address the quality of a scientific report, it serves as a reliable tool for determining the impact that an article, author, and journal has had on the scientific community. In this study we have attempted to develop a resource with detailed information on the 100 most cited articles on metastatic spine disease. We provide insights into the historical development and recent advances within the field.

\section{Acknowledgments}

We would like to thank Ms. Linda Hartman and the librarian staff at University of Pittsburgh Health Sciences Library for their instruction and advice on the study. 


\section{References}

1. Akeyson EW, McCutcheon IE: Single-stage posterior vertebrectomy and replacement combined with posterior instrumentation for spinal metastasis. J Neurosurg 85:211-220, 1996

2. Algra PR, Bloem JL, Tissing H, Falke THM, Arndt JW, Verboom LJ: Detection of vertebral metastases: comparison between MR imaging and bone scintigraphy. Radiographics 11:219-232, 1991

3. Arguello F, Baggs RB, Duerst RE, Johnstone L, McQueen $\mathrm{K}$, Frantz CN: Pathogenesis of vertebral metastasis and epidural spinal cord compression. Cancer 65:98-106, 1990

4. Avrahami E, Tadmor R, Dally O, Hadar H: Early MR demonstration of spinal metastases in patients with normal radiographs and CT and radionuclide bone scans. J Comput Assist Tomogr 13:598-602, 1989

5. Bach F, Larsen BH, Rohde K, Børgesen SE, Gjerris F, Bøge-Rasmussen T, et al: Metastatic spinal cord compression. Occurrence, symptoms, clinical presentations and prognosis in 398 patients with spinal cord compression. Acta Neurochir (Wien) 107:37-43, 1990

6. Barragán-Campos HM, Vallée JN, Lo D, Cormier E, Jean B, Rose M, et al: Percutaneous vertebroplasty for spinal metastases: complications. Radiology 238:354-362, 2006

7. Barron KD, Hirano A, Araki S, Terry RD: Experiences with metastatic neoplasms involving the spinal cord. Neurology 9:91-106, 1959

8. Bartels RHMA, van der Linden YM, van der Graaf WTA: Spinal extradural metastasis: review of current treatment options. CA Cancer J Clin 58:245-259, 2008

9. Batson OV: The function of the vertebral veins and their role in the spread of metastases. Ann Surg 112:138-149, 1940

10. Bauer HCF, Wedin R: Survival after surgery for spinal and extremity metastases. Prognostication in 241 patients. Acta Orthop Scand 66:143-146, 1995

11. Bilsky MH, Boland P, Lis E, Raizer JJ, Healey JH: Singlestage posterolateral transpedicle approach for spondylectomy, epidural decompression, and circumferential fusion of spinal metastases. Spine (Phila Pa 1976) 25:2240-2250, 2000

12. Bilsky MH, Lis E, Raizer J, Lee H, Boland P: The diagnosis and treatment of metastatic spinal tumor. Oncologist 4:459469, 1999

13. Black P: Spinal metastasis: current status and recommended guidelines for management. Neurosurgery 5:726-746, 1979

14. Böhm P, Huber J: The surgical treatment of bony metastases of the spine and limbs. J Bone Joint Surg Br 84:521-529, 2002

15. Byrne TN: Spinal cord compression from epidural metastases. N Engl J Med 327:614-619, 1992

16. Byun WM, Shin SO, Chang Y, Lee SJ, Finsterbusch J, Frahm J: Diffusion-weighted MR imaging of metastatic disease of the spine: assessment of response to therapy. AJNR Am J Neuroradiol 23:906-912, 2002

17. Carmody RF, Yang PJ, Seeley GW, Seeger JF, Unger EC, Johnson JE: Spinal cord compression due to metastatic disease: diagnosis with MR imaging versus myelography. Radiology 173:225-229, 1989

18. Castillo M, Arbelaez A, Smith JK, Fisher LL: Diffusionweighted MR imaging offers no advantage over routine noncontrast MR imaging in the detection of vertebral metastases. AJNR Am J Neuroradiol 21:948-953, 2000

19. Chang EL, Shiu AS, Lii MF, Rhines LD, Mendel E, Mahajan A, et al: Phase I clinical evaluation of near-simultaneous computed tomographic image-guided stereotactic body radiotherapy for spinal metastases. Int J Radiat Oncol Biol Phys 59:1288-1294, 2004
20. Chang EL, Shiu AS, Mendel E, Mathews LA, Mahajan A, Allen PK, et al: Phase I/II study of stereotactic body radiotherapy for spinal metastasis and its pattern of failure. J Neurosurg Spine 7:151-160, 2007

21. Cole JS, Patchell RA: Metastatic epidural spinal cord compression. Lancet Neurol 7:459-466, 2008

22. Connolly ES Jr, Winfree CJ, McCormick PC, Cruz M, Stein BM: Intramedullary spinal cord metastasis: report of three cases and review of the literature. Surg Neurol 46:329-338, 1996

23. Constans JP, de Divitiis E, Donzelli R, Spaziante R, Meder JF, Haye C: Spinal metastases with neurological manifestations. Review of 600 cases. J Neurosurg 59:111-118, 1983

24. DeWald RL, Bridwell KH, Prodromas C, Rodts MF: Reconstructive spinal surgery as palliation for metastatic malignancies of the spine. Spine (Phila Pa 1976) 10:21-26, 1985

25. Dunn RC Jr, Kelly WA, Wohns RNW, Howe JF: Spinal epidural neoplasia. A 15-year review of the results of surgical therapy. J Neurosurg 52:47-51, 1980

26. Edelson RN, Deck MDF, Posner JB: Intramedullary spinal cord metastases. Clinical and radiographic findings in nine cases. Neurology 22:1222-1231, 1972

27. Enkaoua EA, Doursounian L, Chatellier G, Mabesoone F, Aimard T, Saillant G: Vertebral metastases: a critical appreciation of the preoperative prognostic Tokuhashi score in a series of 71 cases. Spine (Phila Pa 1976) 22:2293-2298, 1997

28. Erlich SS, Davis RL: Spinal subarachnoid metastasis from primary intracranial glioblastoma multiforme. Cancer 42:2854-2864, 1978

29. Fornasier VL, Horne JG: Metastases to the vertebral column. Cancer 36:590-594, 1975

30. Garfield E: Citation analysis as a tool in journal evaluation. Science 178: 471-479, 1972

31. Gellad FE, Sadato N, Numaguchi Y, Levine AM: Vascular metastatic lesions of the spine: preoperative embolization. Radiology 176:683-686, 1990

32. Gerszten PC, Burton SA, Ozhasoglu C, Vogel WJ, Welch $\mathrm{WC}$, Baar J, et al: Stereotactic radiosurgery for spinal metastases from renal cell carcinoma. J Neurosurg Spine 3:288-295, 2005

33. Gerszten PC, Burton SA, Ozhasoglu C, Welch WC: Radiosurgery for spinal metastases: clinical experience in 500 cases from a single institution. Spine (Phila Pa 1976) 32:193-199, 2007

34. Ghogawala Z, Mansfield FL, Borges LF: Spinal radiation before surgical decompression adversely affects outcomes of surgery for symptomatic metastatic spinal cord compression. Spine (Phila Pa 1976) 26:818-824, 2001

35. Gibbs IC, Kamnerdsupaphon P, Ryu MR, Dodd R, Kiernan $M$, Chang SD, et al: Image-guided robotic radiosurgery for spinal metastases. Radiother Oncol 82:185-190, 2007

36. Gilbert RW, Kim JH, Posner JB: Epidural spinal cord compression from metastatic tumor: diagnosis and treatment. Ann Neurol 3:40-51, 1978

37. Gokaslan ZL, York JE, Walsh GL, McCutcheon IE, Lang FF, Putnam JB Jr, et al: Transthoracic vertebrectomy for metastatic spinal tumors. J Neurosurg 89:599-609, 1998

38. Greenberg HS, Kim JH, Posner JB: Epidural spinal cord compression from metastatic tumor: results with a new treatment protocol. Ann Neurol 8:361-366, 1980

39. Grem JL, Burgess J, Trump DL: Clinical features and natural history of intramedullary spinal cord metastasis. Cancer 56:2305-2314, 1985

40. Gynning I, Langelan P, Lindberg S, Waldeskog B: Localization with $\mathrm{Sr}^{85}$ of spinal metastases in mammary cancer and changes in uptake after hormone and roentgen therapy. Acta Radiol 55:119-128, 1961 
41. Harrington KD: Anterior cord decompression and spinal stabilization for patients with metastatic lesions of the spine. J Neurosurg 61:107-117, 1984

42. Harrington KD: Anterior decompression and stabilization of the spine as a treatment for vertebral collapse and spinal cord compression from metastatic malignancy. C Clin Orthop Relat Res 223:177-197, 1988

43. Harrington KD: Metastatic disease of the spine. J Bone Joint Surg Am 68:1110-1115, 1986

44. Harrington KD: The use of methylmethacrylate for vertebral-body replacement and anterior stabilization of pathological fracture-dislocations of the spine due to metastatic malignant disease. J Bone Joint Surg Am 63:36-46, 1981

45. Helweg-Larsen S: Clinical outcome in metastatic spinal cord compression. A prospective study of 153 patients. Acta Neurol Scand 94:269-275, 1996

46. Helweg-Larsen S, Sørensen PS: Symptoms and signs in metastatic spinal cord compression: a study of progression from first symptom until diagnosis in 153 patients. Eur J Cancer 30A:396-398, 1994

47. Helweg-Larsen S, Sørensen PS, Kreiner S: Prognostic factors in metastatic spinal cord compression: a prospective study using multivariate analysis of variables influencing survival and gait function in 153 patients. Int J Radiat Oncol Biol Phys 46:1163-1169, 2000

48. Herneth AM, Philipp MO, Naude J, Funovics M, Beichel RR, Bammer R, et al: Vertebral metastases: assessment with apparent diffusion coefficient. Radiology 225:889-894, 2002

49. Hirabayashi H, Ebara S, Kinoshita T, Yuzawa Y, Nakamura I, Takahashi J, et al: Clinical outcome and survival after palliative surgery for spinal metastases: palliative surgery in spinal metastases. Cancer 97:476-484, 2003

50. Ibrahim A, Crockard A, Antonietti P, Boriani S, Bünger C, Gasbarrini A, et al: Does spinal surgery improve the quality of life for those with extradural (spinal) osseous metastases? An international multicenter prospective observational study of 223 patients. Invited submission from the Joint Section Meeting on Disorders of the Spine and Peripheral Nerves, March 2007. J Neurosurg Spine 8:271-278, 2008

51. Ioannidis JPBK, Boyack KW, Small H, Sorensen AA, Klavans R: Bibliometrics: Is your most cited work your best? Nature 514:561-562, 2014

52. Jellinger K, Kothbauer P, Sunder-Plassmann E, Weiss R: Intramedullary spinal cord metastases. J Neurol 220:31-41, 1979

53. Kaemmerlen P, Thiesse P, Jonas P, Bérard CL, Duquesnel $\mathrm{J}$, Bascoulergue Y, et al: Percutaneous injection of orthopedic cement in metastatic vertebral lesions. N Engl J Med 321:121, 1989

54. Kelly JC, Glynn RW, O'Briain DE, Felle P, McCabe JP: The 100 classic papers of orthopaedic surgery: a bibliometric analysis. J Bone Joint Surg Br 92:1338-1343, 2010

55. Klimo P Jr, Schmidt MH: Surgical management of spinal metastases. Oncologist 9:188-196, 2004

56. Klimo P Jr, Thompson CJ, Kestle JRW, Schmidt MH: A meta-analysis of surgery versus conventional radiotherapy for the treatment of metastatic spinal epidural disease. Neuro Oncol 7:64-76, 2005

57. Leithner A, Radl R, Gruber G, Hochegger M, Leithner K, Welkerling $\mathrm{H}$, et al: Predictive value of seven preoperative prognostic scoring systems for spinal metastases. Eur Spine J 17:1488-1495, 2008

58. Livingston KE, Perrin RG: The neurosurgical management of spinal metastases causing cord and cauda equina compression. J Neurosurg 49:839-843, 1978

59. MacRoberts MH, MacRoberts BR: Problems of citation analysis. Soc Work Res Abstr 28:4, 1992 (Letter)

60. Maranzano E, Bellavita R, Rossi R, De Angelis V,
Frattegiani A, Bagnoli R, et al: Short-course versus splitcourse radiotherapy in metastatic spinal cord compression: results of a phase III, randomized, multicenter trial. J Clin Oncol 23:3358-3365, 2005

61. Maranzano E, Latini P: Effectiveness of radiation therapy without surgery in metastatic spinal cord compression: final results from a prospective trial. Int J Radiat Oncol Biol Phys 32:959-967, 1995

62. Maranzano E, Latini P, Checcaglini F, Ricci S, Panizza BM, Aristei C, et al: Radiation therapy in metastatic spinal cord compression. A prospective analysis of 105 consecutive patients. Cancer 67:1311-1317, 1991

63. McCain KW: Assessing obliteration by incorporation in a full-text database: JSTOR, economics, and the concept of "bounded rationality." Scientometrics 101:1445-1459, 2014

64. Milker-Zabel S, Zabel A, Thilmann C, Schlegel W, Wannenmacher M, Debus J: Clinical results of retreatment of vertebral bone metastases by stereotactic conformal radiotherapy and intensity-modulated radiotherapy. Int J Radiat Oncol Biol Phys 55:162-167, 2003

65. Patchell RA, Tibbs PA, Regine WF, Payne R, Saris S, Kryscio RJ, et al: Direct decompressive surgical resection in the treatment of spinal cord compression caused by metastatic cancer: a randomised trial. Lancet 366:643-648, 2005

66. Rades D, Fehlauer F, Schulte R, Veninga T, Stalpers LJ, Basic H, et al: Prognostic factors for local control and survival after radiotherapy of metastatic spinal cord compression. J Clin Oncol 24:3388-3393, 2006

67. Rades D, Heidenreich F, Karstens JH: Final results of a prospective study of the prognostic value of the time to develop motor deficits before irradiation in metastatic spinal cord compression. Int J Radiat Oncol Biol Phys 53:975-979, 2002

68. Rades D, Stalpers LJA, Veninga T, Schulte R, Hoskin PJ, Obralic N, et al: Evaluation of five radiation schedules and prognostic factors for metastatic spinal cord compression. J Clin Oncol 23:3366-3375, 2005

69. Rodichok LD, Harper GR, Ruckdeschel JC, Price A, Roberson G, Barron KD, et al: Early diagnosis of spinal epidural metastases. Am J Med 70:1181-1188, 1981

70. Rodriguez M, Dinapoli RP: Spinal cord compression: with special reference to metastatic epidural tumors. Mayo Clin Proc 55:442-448, 1980

71. Rose PS, Laufer I, Boland PJ, Hanover A, Bilsky MH, Yamada J, et al: Risk of fracture after single fraction imageguided intensity-modulated radiation therapy to spinal metastases. J Clin Oncol 27:5075-5079, 2009

72. Ryu S, Rock J, Rosenblum M, Kim JH: Patterns of failure after single-dose radiosurgery for spinal metastasis. J Neurosurg 101 (Suppl 3):402-405, 2004

73. Ryu S, Yin FF, Rock J, Zhu J, Chu A, Kagan E, et al: Imageguided and intensity-modulated radiosurgery for patients with spinal metastasis. Cancer 97:2013-2018, 2003

74. Sahgal A, Ames C, Chou D, Ma L, Huang K, Xu W, et al: Stereotactic body radiotherapy is effective salvage therapy for patients with prior radiation of spinal metastases. Int $\mathbf{J}$ Radiat Oncol Biol Phys 74:723-731, 2009

75. Sahgal A, Larson DA, Chang EL: Stereotactic body radiosurgery for spinal metastases: a critical review. Int J Radiat Oncol Biol Phys 71:652-665, 2008

76. Schaberg J, Gainor BJ: A profile of metastatic carcinoma of the spine. Spine (Phila Pa 1976) 10:19-20, 1985

77. Schiff D, O’Neill BP: Intramedullary spinal cord metastases: clinical features and treatment outcome. Neurology 47:906-912, 1996

78. Scoville WB, Palmer AH, Samra K, Chong G: Use of acrylic plastic for vertebral replacement of fixation in metastatic disease of spine. J Neurosurg 27:274-279, 1967 
79. Sioutos PJ, Arbit E, Meshulam CF, Galicich JH: Spinal metastases from solid tumors. Analysis of factors affecting survival. Cancer 76:1453-1459, 1995

80. Skovrlj B, Steinberger J, Guzman JZ, Overley SC, Qureshi SA, Caridi JM, et al: The 100 most influential articles in cervical spine surgery. Global Spine J 6:69-79, 2016

81. Smoker WRK, Godersky JC, Knutzon RK, Keyes WD, Norman D, Bergman W: The role of MR imaging in evaluating metastatic spinal disease. AJR Am J Roentgenol 149:1241-1248, 1987

82. Sørensen S, Børgesen SE, Rohde K, Rasmusson B, Bach F, Bøge-Rasmussen T, et al: Metastatic epidural spinal cord compression. Results of treatment and survival. Cancer 65: $1502-1508,1990$

83. Stark RJ, Henson RA, Evans SJW: Spinal metastases. A retrospective survey from a general hospital. Brain 105:189213,1982

84. Sundaresan N, Rothman A, Manhart K, Kelliher K: Surgery for solitary metastases of the spine: rationale and results of treatment. Spine (Phila Pa 1976) 27:1802-1806, 2002

85. Sundaresan N, Sachdev VP, Holland JF, Moore F, Sung M, Paciucci PA, et al: Surgical treatment of spinal cord compression from epidural metastasis. J Clin Oncol 13:23302335,1995

86. Taneichi H, Kaneda K, Takeda N, Abumi K, Satoh S: Risk factors and probability of vertebral body collapse in metastases of the thoracic and lumbar spine. Spine (Phila Pa 1976) 22:239-245, 1997

87. Tatsui H, Onomura T, Morishita S, Oketa M, Inoue T: Survival rates of patients with metastatic spinal cancer after scintigraphic detection of abnormal radioactive accumulation. Spine (Phila Pa 1976) 21:2143-2148, 1996

88. Tokuhashi Y, Matsuzaki H, Oda H, Oshima M, Ryu J: A revised scoring system for preoperative evaluation of metastatic spine tumor prognosis. Spine (Phila Pa 1976) 30:2186-2191, 2005

89. Tokuhashi Y, Matsuzaki H, Toriyama S, Kawano H, Ohsaka $\mathrm{S}$ : Scoring system for the preoperative evaluation of metastatic spine tumor prognosis. Spine (Phila Pa 1976) 15:1110-1113, 1990

90. Tomita K, Kawahara N, Baba H, Tsuchiya H, Nagata S, Toribatake Y: Total en bloc spondylectomy for solitary spinal metastases. Int Orthop 18:291-298, 1994

91. Tomita K, Kawahara N, Kobayashi T, Yoshida A, Murakami H, Akamaru T: Surgical strategy for spinal metastases. Spine (Phila Pa 1976) 26:298-306, 2001

92. Tomita K, Toribatake Y, Kawahara N, Ohnari H, Kose H: Total en bloc spondylectomy and circumspinal decompression for solitary spinal metastasis. Paraplegia 32:36-46, 1994

93. Tomita T, Galicich JH, Sundaresan N: Radiation therapy for spinal epidural metastases with complete block. Acta Radiol Oncol 22:135-143, 1983

94. van der Linden YM, Dijkstra SP, Vonk EJA, Marijnen CAM, Leer JWH: Prediction of survival in patients with metastases in the spinal column: results based on a randomized trial of radiotherapy. Cancer 103:320-328, 2005

95. Vecht CJ, Haaxma-Reiche H, van Putten WLJ, de Visser M, Vries EP, Twijnstra A: Initial bolus of conventional versus high-dose dexamethasone in metastatic spinal cord compression. Neurology 39:1255-1257, 1989

96. Vertosick FT Jr, Selker RG: Brain stem and spinal metastases of supratentorial glioblastoma multiforme: a clinical series. Neurosurgery 27:516-522, 1990

97. Wang JC, Boland P, Mitra N, Yamada Y, Lis E, Stubblefield $\mathrm{M}$, et al: Single-stage posterolateral transpedicular approach for resection of epidural metastatic spine tumors involving the vertebral body with circumferential reconstruction: results in 140 patients. J Neurosurg Spine 1:287-298, 2004
98. Weigel B, Maghsudi M, Neumann C, Kretschmer R, Müller FJ, Nerlich M: Surgical management of symptomatic spinal metastases. Postoperative outcome and quality of life. Spine (Phila Pa 1976) 24:2240-2246, 1999

99. Weill A, Chiras J, Simon JM, Rose M, Sola-Martinez T, Enkaoua E: Spinal metastases: indications for and results of percutaneous injection of acrylic surgical cement. Radiology 199:241-247, 1996

100. Weissman DE: Glucocorticoid treatment for brain metastases and epidural spinal cord compression: a review. J Clin Oncol 6:543-551, 1988

101. White WA, Patterson RH Jr, Bergland RM: Role of surgery in treatment of spinal cord compression by metastatic neoplasm. Cancer 27:558-561, 1971

102. Wise JJ, Fischgrund JS, Herkowitz HN, Montgomery D, Kurz LT: Complication, survival rates, and risk factors of surgery for metastatic disease of the spine. Spine (Phila Pa 1976) 24:1943-1951, 1999

103. Witham TF, Khavkin YA, Gallia GL, Wolinsky JP, Gokaslan ZL: Surgery insight: current management of epidural spinal cord compression from metastatic spine disease. Nat Clin Pract Neurol 2:87-94, 116, 2006

104. Wong DA, Fornasier VL, MacNab I: Spinal metastases: the obvious, the occult, and the impostors. Spine (Phila Pa 1976) $15: 1-4,1990$

105. Wright RL: Malignant tumors in spinal extradural space: results of surgical treatment. Ann Surg 157:227-231, 1963

106. Yamada Y, Bilsky MH, Lovelock DM, Venkatraman ES, Toner S, Johnson J, et al: High-dose, single-fraction imageguided intensity-modulated radiotherapy for metastatic spinal lesions. Int J Radiat Oncol Biol Phys 71:484-490, 2008

107. Yegros-Yegros A, Rafols I, D’Este P: Does interdisciplinary research lead to higher citation impact? The different effect of proximal and distal interdisciplinarity. PLoS One 10:e0135095, 2015

108. Young RF, Post EM, King GA: Treatment of spinal epidural metastases. Randomized prospective comparison of laminectomy and radiotherapy. J Neurosurg 53:741-748, 1980

109. Zhou XJ, Leeds NE, McKinnon GC, Kumar AJ: Characterization of benign and metastatic vertebral compression fractures with quantitative diffusion MR imaging. AJNR Am J Neuroradiol 23:165-170, 2002

\section{Disclosures}

The authors report no conflict of interest concerning the materials or methods used in this study or the findings specified in this paper.

\section{Author Contributions}

Conception and design: Hamilton, Cohen, Alan. Acquisition of data: Cohen, Alan. Analysis and interpretation of data: Hamilton, Cohen. Drafting the article: Cohen, Alan, Zhou. Critically revising the article: Hamilton, Cohen, Alan. Reviewed submitted version of manuscript: Hamilton, Cohen, Alan. Approved the final version of the manuscript on behalf of all authors: Hamilton. Statistical analysis: Cohen. Study supervision: Hamilton.

\section{Supplemental Information Videos}

Video Abstract. https://vimeo.com/172402982.

\section{Correspondence}

D. Kojo Hamilton, Department of Neurological Surgery, University of Pittsburgh Medical Center, 200 Lothrop St., Ste. B-400, Pittsburgh, PA 15213-2582. email: kojohamilton1@gmail. com. 